ISSN 0258-7122

Bangladesh J. Agril. Res. 33(3) : 469-477, September 2008

\title{
EFFECT OF STORAGE CONTAINERS AND TIME ON SEED QUALITY OF WHEAT
}

\author{
P.K. MALAKER ${ }^{1}$, I.H. MIAN ${ }^{2}$, K.A. BHUIYAN ${ }^{3}$ \\ A.M. AKANDA ${ }^{4}$ AND M.M.A. REZA ${ }^{5}$
}

\begin{abstract}
A study was undertaken to determine the prevalence of black point and percentages of germination, moisture content and different fungi associated with wheat seeds during storage in different types of container. Seeds of a widely cultivated variety Kanchan were stored in five types of containers viz., 'dole'(bamboo made), earthen pitcher, tin container, polyethylene bag and refrigerator $\left(10^{\circ} \mathrm{C}\right)$ for ten months at room temperature. Samples were taken at monthly interval beginning from the month of April (prior to storage). The seed moisture content and black point severity were found highest in dole resulting in the lowest percentage of seed germination. The highest germination percentage was observed under storage in refrigerator followed by polyethylene bag, tin container and earthen pitcher. The moisture content and black point infection increased and seed germination decreased with the increase of storage period. Prior to storage in April, the seed germination was 95\%, which decreased to about $75 \%$ at the end often months of storage (in January). Various fungal flora associated with wheat seeds differed in their prevalence depending on the length of storage period and types of container used for storage. The population of field fungi viz., Alternaria alternata, Aiternaria triticina, Bipolaris sorokiniana, Cladosporium cladosporioides, Curvularia lunata, Epicoccum purpurascens and Fusarium spp. decreased while that of storage fungi viz., Aspergillus, Chaetomium, Nigrospora, Penicillium and Rhizopus increased with the progress of storage period.
\end{abstract}

Key Words: Storage, seed quality, wheat.

\section{Introduction}

Quality characters of wheat seed, such as seed germination, moisture content, seed discolouration and seed-borne fungal prevalence have long been known to be influenced by various factors during storage. The field fungi like Alternaria, Cladosporium, Curvularia, Fusarium and Helminthosporium invade seeds as they are developing on the plants in the field or after they have matured, but before they are harvested (Christensen and Kaufmann, 1965). These fungi usually do not continue to grow in grains after harvest, but may remain alive for years in grains stored at low moisture content and low temperature (Christensen, 1963). The field fungi may induce seed discolouration,

\footnotetext{
${ }^{1 \& 5}$ Senior Scientific Officer, Wheat Research Centre (WRC), BARI, Nashipur, Dinajpur5200, ${ }^{2,3 \& 4}$ Professor, BSMRAU, Gazipur-1706, Bangladesh.
} 
commonly known as black point or kernel smudge, cause death of the ovules, shrivelling of the kernels and weakening or death of the embryos (Hanson and Christensen, 1953). In general, the damage caused by field fungi is done by the time the grains are harvested, although invasion of the developing or mature embryos of cereal seeds by Fusarium may result in development of discoloured embryos during storage.

The storage fungi, mainly comprising several species of Aspergillus and Penicillium, do not invade grains to any appreciable degree or extent before harvest (Tuite, 1961), but they can cause severe discolouration of seed in storage resulting in germination failure, discoloured or otherwise damaged embryos or whole seeds, and production of mycotoxins that constitute a health hazard for man and animals (Dharam Vir, 1974; Christensen and Kaufmann, 1979; Mehrotra, 1983; Bilgrami and Sinha, 1983; Dharam Vir, 1986). Each species or group of species of Aspergillus has its own rather sharply defined lower limit of moisture content usually between 13 and 18\% for invasion of stored grains. Species of Penicillium are encountered at times, usually in seed lots stored at low temperatures and with above $16 \%$ moisture content. In the range of moisture content between 14.0 and $15.5 \%$ in wheat, a difference of only $0.2 \%$ may make a great difference in the rate of invasion of the grain by storage fungi and in the damage caused to the grain (Christensen and Kaufmann, 1964). In general, storage fungi grow most rapidly on moist grain at a temperature of about $30^{\circ} \mathrm{C}$, and at 12 to $15^{\circ} \mathrm{C}$, most storage fungi grow very slowly on grains with 15 to $16 \%$ moisture contents. Therefore, any method of storage, which is aimed at preventing or retarding the invasion of these fungi and creating unfavourable conditions for their growth and multiplication will help in improving the quality of seed.

In Bangladesh, only $15-20 \%$ of the total quantity of wheat seed required for planting is supplied by Bangladesh Agricultural Development Corporation (BADC) and other seed producing agencies, where large seed godowns with moderate cooling and periodic drying facilities are available. The rest $80-85 \%$ of the total requirement of wheat seed is usually met up through farmer to farmer exchange of seeds stored in different kinds of small to medium sized containers kept at room temperatures. Although considerable research works have been done on various aspects of field disease management of wheat and useful findings were obtained, the information on its storage behaviour in relation to seed quality and seed health is limited in the country (Rahman et al., 1985; Islam and Fakir, 1988). The present study was, therefore, undertaken with the objective 
to determine the role of different storage containers and length of storage period on various seed quality characters and seed-borne fungal prevalence of wheat.

\section{Materials and Method}

Five types of storage containers viz., 'dole'(made of bamboo), earthen pitcher, tin container, polyethylene bag and refrigerator were used in this study. Dole, earthen pitcher and tin container were coated with paint before use. Freshly harvested seeds of a widely cultivated wheat variety Kanchan were sun-dried for two days and five kg seeds were poured into each container on 7 April 2000. In case of refrigerator, the seeds were kept in polyethylene bag. Except the refrigerator maintained at $10^{\circ} \mathrm{C}$, all other containers were placed on a wooden rack at room temperature $\left(25-30 \pm 2^{\circ} \mathrm{C}\right)$ in a brick-built room of the laboratory of Bangabandhu Sheikh Mujibur Rahman Agricultural University, Gazipur. The seeds kept in different containers were stored for ten months upto January 2001. Samples of seeds were drawn from each container at monthly intervals (30 days) beginning from April (prior to storage) upto January. Data on moisture content, black point incidence, germination and prevalence of fungi were recorded. Moisture contents of seeds stored in various containers were recorded using a digital moisture meter. The percentage of black point incidence and black point index were calculated on 0-5 scale by observation of randomly taken 400 seeds of each sample drawn from each container. The germination percentage and prevalence of different fungi were determined by blotter method following ISTA rules (Anon., 1996). Whenever necessary, the data were transformed according to square root transformation method and analyzed statistically using MSTAT-C computer programme. Duncan's Multiple Range Test was followed for comparing treatment means.

\section{Results and Discussion}

The severity of black point infection, germination and moisture content of wheat seeds varied with the variation of storage container (Table 1). Percent black pointed seed, percent black point index and moisture content were maximal when the seeds were stored in dole, which was followed by earthen pitcher, tin container, polyethylene bag and refrigerator. On the other hand, percent germination was found highest when the seeds were stored in refrigerator, which was followed by polyethylene bag, tin container, earthen pitcher and dole. Effect of the five containers on moisture content and seed germination were significantly different from each other. 
Table 1. Effect of different storage containers on black point incidence, germination and moisture content of wheat seeds.

\begin{tabular}{l|l|l|l|l}
\hline \multicolumn{1}{c}{ Storage containers } & \multicolumn{1}{c}{$\begin{array}{c}\text { Percent black } \\
\text { pointed seeds }^{\mathrm{x}}\end{array}$} & $\begin{array}{c}\text { Percent black } \\
\text { point index }^{\mathrm{y}}\end{array}$ & $\begin{array}{c}\text { Germination } \\
(\%)^{\mathrm{X}}\end{array}$ & $\begin{array}{c}\text { Moisture } \\
\text { content }^{(\%)^{\mathrm{X}}}\end{array}$ \\
\hline Dole & $24.11 \mathrm{a}$ & $10.52 \mathrm{a}$ & $68.38 \mathrm{e}$ & $13.76 \mathrm{a}$ \\
Earthenpitcher & $(4.88)$ & $(3.29)$ & $(8.09)$ & $(3.70)$ \\
& $20.81 \mathrm{~b}$ & $9.63 \mathrm{~b}$ & $87.30 \mathrm{~d}$ & $12.65 \mathrm{~b}$ \\
Tincontainer & $(4.55)$ & $(3.16)$ & $(9.34)$ & $(3.55)$ \\
& $18.86 \mathrm{c}$ & $9.06 \mathrm{~b}$ & $91.18 \mathrm{c}$ & $11.86 \mathrm{c}$ \\
Polyethylene bag & $(4.34)$ & $(3.08)$ & $(9.55)$ & $(3.44)$ \\
& $18.34 \mathrm{~cd}$ & $8.29 \mathrm{c}$ & $92.93 \mathrm{~b}$ & $11.17 \mathrm{~d}$ \\
Refrigerator $\left(10^{\circ} \mathrm{C}\right)$ & $(4.28)$ & $(2.96)$ & $(9.64)$ & $(3.34)$ \\
& $17.89 \mathrm{~d}$ & $7.68 \mathrm{~d}$ & $94.75 \mathrm{a}$ & $10.97 \mathrm{e}$ \\
\hline LSD $(0.05)$ & $(4.22)$ & $(2.85)$ & $(9.73)$ & $(3.31)$ \\
\hline
\end{tabular}

Means within a column followed by a common letter do not differ significantly $(\mathrm{p}=0.05)$.

${ }^{\mathrm{x}}$ Data within parentheses are square root $(\mathrm{x})$ transformed value

${ }^{\mathrm{y}}$ Data within parentheses are square root $(\mathrm{x}+0.5)$ transformed values.

The effects of storage period on black point incidence, black point index, germination and moisture content of wheat seeds are presented in Table 2. At the time of storage in April, $17.50 \%$ seeds showed symptoms of black point, and the percent black point index was 7.31. Both of these parameters related to severity of black point were statistically similar during April to July. Significant increase in severity of black point over the initial month (April) of storage was recorded from August. The increase in percent black pointed seed and black point index continued upto the last month (January) of storage. The incidence of black point affected seeds during the months of September to January was statistically similar. The black point index was the highest in January, which was statistically similar to that recorded in December, but significantly higher as compared to other months of storage. The percentages of seed germination recorded during the first four months (April-July) of storage were statistically similar. Significant reduction in germination compared to the previous months started from August and it continued upto the last month (January) of storage, when only $74.55 \%$ seeds germinated. The initial moisture content of seed recorded in April was $10.70 \%$, which was statistically similar to that recorded in May. The moisture content started to increase from June and the increasing trend continued upto January, when the moisture content reached $13.66 \%$. The monthly increases in moisture content recorded from June to January were significantly different from each other.

Two distinct ecological groups of fungi viz., 'field fungi' and 'storage fungi' were recorded from wheat seeds during storage in different types of container 
(Table 3). The field fungi were: Alternaria alternata, Alternaria triticina, Bipolaris sorokiniana, Cladosporium cladosporioides, Curvularia lunata, Epicoccum purpurascens and Fusarium spp. The storage fungi were: Aspergillus spp., Chaetomium spp., Nigrospora sp., Penicillium spp. and Rhizopus sp. Among the field fungi, $B$. sorokiniana appeared to be most predominant, which was followed by A. alternata, C. lunata and Fusarium spp. In case of storage fungi, Aspergillus and Nigrospora were more prevalent than the others. Prevalence of both field and storage fungi associated with wheat seeds varied among different types of container used. The populations of field fungi were highest in refrigerator, which were followed by polyethylene bag, tin container and earthen pitcher, while the lowest prevalence of these fungi were observed when the seeds were stored in dole. On the other hand, the highest populations of storage ftingi were observed in dole, which were followed by earthen pitcher, tin container and polyethylene bag, and the lowest incidence of these fungi were recorded in case of seeds stored in refrigerator.

Table 2. Effect of storage period on black point incidence, germination and moisture content of wheat seeds.

\begin{tabular}{|c|c|c|c|c|}
\hline Storage period (months) & $\begin{array}{l}\text { Percent black } \\
\text { pointed seeds }\end{array}$ & $\begin{array}{l}\text { Percent black } \\
\text { point index }\end{array}$ & $\begin{array}{c}\text { Germination } \\
(\%)^{\mathrm{X}}\end{array}$ & $\begin{array}{c}\text { Moisture } \\
\text { content }(\%)^{\mathrm{X}}\end{array}$ \\
\hline April & $\begin{array}{l}17.50 \mathrm{c} \\
(4.18)\end{array}$ & $\begin{array}{l}7.31 \mathrm{~g} \\
(2.79)\end{array}$ & $\begin{array}{l}95.00 \mathrm{a} \\
(9.75)\end{array}$ & $\begin{array}{l}10.70 \mathrm{i} \\
(3.27)\end{array}$ \\
\hline May & $\begin{array}{l}17.40 \mathrm{c} \\
(4.17)\end{array}$ & $\begin{array}{l}7.32 \mathrm{~g} \\
(2.79)\end{array}$ & $\begin{array}{l}95.25 \mathrm{a} \\
(9.76)\end{array}$ & $\begin{array}{l}10.77 \mathrm{i} \\
(3.28)\end{array}$ \\
\hline June & $\begin{array}{l}17.91 \mathrm{c} \\
(4.23)\end{array}$ & $\begin{array}{l}7.47 \mathrm{~g} \\
(2.82)\end{array}$ & $\begin{array}{l}94.70 \mathrm{a} \\
(9.73)\end{array}$ & $\begin{array}{l}10.96 \mathrm{~h} \\
(3.31)\end{array}$ \\
\hline July & $\begin{array}{l}18.56 \mathrm{c} \\
(4.30)\end{array}$ & $\begin{array}{l}7.78 \mathrm{fg} \\
(2.87)\end{array}$ & $\begin{array}{l}93.90 \mathrm{a} \\
(9.69)\end{array}$ & $\begin{array}{l}11.24 \mathrm{~g} \\
(3.35)\end{array}$ \\
\hline August & $\begin{array}{l}20.00 \mathrm{~b} \\
(4.46)\end{array}$ & $\begin{array}{l}8.47 \mathrm{ef} \\
(2.99)\end{array}$ & $\begin{array}{l}91.85 b \\
(9.58)\end{array}$ & $\begin{array}{l}11.61 \mathrm{f} \\
(3.41)\end{array}$ \\
\hline September & $\begin{array}{l}20.80 a b \\
(4.54)\end{array}$ & $\begin{array}{l}9.23 \mathrm{de} \\
(3.11)\end{array}$ & $\begin{array}{l}85.95 \mathrm{c} \\
(9.25)\end{array}$ & $\begin{array}{l}12.67 \mathrm{e} \\
(3.50)\end{array}$ \\
\hline October & $\begin{array}{l}\text { 21.34ab } \\
(4.60)\end{array}$ & $\begin{array}{l}\text { 9.89cd } \\
(3.21)\end{array}$ & $\begin{array}{l}82.35 \mathrm{~d} \\
(9.03)\end{array}$ & $\begin{array}{l}12.78 \mathrm{~d} \\
(3.57)\end{array}$ \\
\hline November & $\begin{array}{l}21.92 \mathrm{a} \\
(4.66)\end{array}$ & $\begin{array}{l}\text { 10.45bc } \\
(3.30)\end{array}$ & $\begin{array}{l}79.25 \mathrm{e} \\
(8.82)\end{array}$ & $\begin{array}{l}13.27 \mathrm{c} \\
(3.64)\end{array}$ \\
\hline December & $\begin{array}{l}22.16 \mathrm{a} \\
(4.68)\end{array}$ & $\begin{array}{l}11.11 \mathrm{ab} \\
(3.39)\end{array}$ & $\begin{array}{l}76.25 f \\
(8.61)\end{array}$ & $\begin{array}{l}13.53 \mathrm{~b} \\
(3.67)\end{array}$ \\
\hline January & $\begin{array}{l}22.41 \mathrm{a} \\
(4.71)\end{array}$ & $\begin{array}{l}11.34 \mathrm{a} \\
(3.42)\end{array}$ & $\begin{array}{l}74.55 g \\
(8.47)\end{array}$ & $\begin{array}{l}13.66 \mathrm{a} \\
(3.69)\end{array}$ \\
\hline LSD (0.05) & 0.15 & 0.12 & 0.09 & 0.01 \\
\hline
\end{tabular}

Means within a column followed by a common letter do not differ significantly $(\mathrm{p}=0.05)$.

${ }^{\mathrm{x}}$ Data within parentheses are square root $(\mathrm{x})$ transformed values.

${ }^{\mathrm{x}}$ Data within parentheses are square root $(\mathrm{x}+0.5)$ transformed values. 
Table 3. Prevalence of fungi associated with wheat seeds stored in different containers.

\begin{tabular}{|c|c|c|c|c|c|c|c|c|c|c|c|c|}
\hline \multirow{3}{*}{$\begin{array}{l}\text { Storage } \\
\text { containers }\end{array}$} & \multicolumn{12}{|c|}{ Prevalence of fungi (\%)* } \\
\hline & \multicolumn{7}{|c|}{ Field fungi } & \multicolumn{5}{|c|}{ Storage fungi } \\
\hline & $\mathrm{Aa}$ & At & Bs & Cc & $\mathrm{CI}$ & Ep & $\mathrm{F}$ & A & C & $\mathrm{N}$ & $\mathrm{P}$ & $\mathrm{R}$ \\
\hline Dole & 14.90 & 2.00 & 23.95 & 1.42 & 13.45 & 1.80 & 11.67 & 28.60 & 5.32 & 9.12 & 5.42 & 4.60 \\
\hline $\begin{array}{l}\text { Earthen } \\
\text { pitcher }\end{array}$ & 19.50 & 2.45 & 32.57 & 1.87 & 15.72 & 2.32 & 13.20 & 18.52 & 3.75 & 7.40 & 2.67 & 3.42 \\
\hline Tin & 23.07 & 3.35 & 38.02 & 2.10 & 18.90 & 2.67 & 14.15 & 12.60 & 3.42 & 5.67 & 1.70 & 2.70 \\
\hline $\begin{array}{l}\text { Polyethylene } \\
\text { bag }\end{array}$ & 24.20 & 3.45 & 41.00 & 2.55 & 20.07 & 2.87 & 14.82 & 9.50 & 2.52 & 5.42 & 1.20 & 1.05 \\
\hline $\begin{array}{l}\text { Refrigerator } \\
\left(10^{0} \mathrm{C}\right)\end{array}$ & 28.72 & 4.47 & 42.90 & 4.20 & 21.77 & 3.67 & 15.92 & 2.97 & 0.47 & 3.02 & 0.52 & 0.40 \\
\hline
\end{tabular}

*Based on seed health test of 4000 seeds for each container by blotter method.

$\mathrm{Aa}=$ Alternaria alternata, $\mathrm{At}=$ Alternaria triticina, $\mathrm{Bs}=$ Bipolaris sorokiniana, $\mathrm{Cc}=$ cladisporium cladosporioides, $\mathrm{Cl}=$ Curvularia lunata, $\mathrm{Ep}=$ Epicoccum purpurascens, $\mathrm{F}=$ Aspergillus, $\mathrm{C}=$ Chaetomium, $\mathrm{N}=$ Nigrospora, $\mathrm{P}=$ Pen icillium and $\mathrm{R}=$ Rhizopus .

The populations of field fungi decreased while those of storage fungi increased with the progress of storage period (Table 4). In case of field fungi, the reductions in seed-borne incidence of A. triticina, C. cladosporioides and E. purpurascens were more pronounced although their populations were much lower compared to others. Among the storage fungi, the highest increase in population was observed with Aspergillus spp., which showed only $3.50 \%$ incidence initially and as high as $27.10 \%$ in the last month of storage. In general, the increase or decrease in seed-borne fungal prevalence was gradual throughout the storage period except in the month of August when the increase or decrease was relatively sharp for majority of the fungi detected.

Table 4. Prevalence of fungi associated with wheat seeds in different months during storage.

\begin{tabular}{|c|c|c|c|c|c|c|c|c|c|c|c|c|}
\hline \multirow{3}{*}{$\begin{array}{c}\text { Storage } \\
\text { containers }\end{array}$} & \multicolumn{12}{|c|}{ Prevalence of fungi (\%)* } \\
\hline & \multicolumn{7}{|c|}{ Field fungi } & \multicolumn{5}{|c|}{ Storage fungi } \\
\hline & $\mathrm{Aa}$ & At & Bs & Cc & $\mathrm{CI}$ & Ep & $\mathrm{F}$ & A & $\mathrm{C}$ & $\mathrm{N}$ & $\mathrm{P}$ & $\mathrm{R}$ \\
\hline April & 30.00 & 5.00 & 43.50 & 5.25 & 23.00 & 5.00 & 16.75 & 3.50 & 0.75 & 4.25 & 0.50 & 1.00 \\
\hline May & 0 & 4.55 & 5 & 4.75 & 22 & 4.85 & 16.40 & 3.80 & 0.90 & & .85 & 1.25 \\
\hline Jur & 0 & 4.4 & & 4.30 & 21 & 4.40 & 15.75 & 4.45 & 0.80 & & 0 & \\
\hline & & 3.60 & 0 & 3.55 & 20.45 & 3.75 & 14.95 & 7.50 & 5 & & 0 & 1.85 \\
\hline & & 3.20 & 36.70 & 1.7 & 17.95 & 2.90 & 14.60 & 11.70 & 1.30 & 5.2 & 2.70 & 2.95 \\
\hline & 0 & 3.10 & 34.10 & 1.55 & 16.90 & 2.00 & 13.20 & 14.85 & 2.55 & & 3.10 & 2.80 \\
\hline & 0 & 2.35 & 25 & 1.10 & 15.75 & 1.50 & 12.85 & 22.10 & 4.60 & 7. & 3.10 & 3.15 \\
\hline & & 1.95 & 29.65 & 1.00 & 14.70 & 1.10 & 12.55 & 24.10 & 6.15 & 7.60 & 3.35 & 3.30 \\
\hline & .90 & 1.65 & 28.95 & 0.55 & 13.85 & 0.70 & 11.65 & 25.30 & 6.50 & 8.45 & 3.10 & 3.35 \\
\hline January & 14.65 & 1.55 & 28.20 & 0.50 & 13.55 & 0.50 & 10.85 & 27.10 & 6.20 & 9.00 & 3.25 & 3.40 \\
\hline
\end{tabular}

* Based on seed health testing of 2000 seeds for each month by blotter method.

$\mathrm{Aa}=$ Alternaria alternata, $\mathrm{At}=$ Alternaria triticina, $\mathrm{Bs}=$ Bipolaris sorokiniana, $\mathrm{Cc}=$ Cladosporium cladosporioides, $\mathrm{CI}=$ Curvularia lunata, $\mathrm{Ep}=$ Epicoccum purpurascens, $\mathrm{F}=$ Fusarium, $\mathrm{A}=$ Aspergillus, $\mathrm{C}=$ Chaetomium, $\mathrm{N}=$ Nigrospora, $\mathrm{P}=$ Penicillium and $\mathrm{R}=$ Rhizopus. 
The results of the present study indicate that moisture content and black point incidence of wheat seeds stored in different types of container increased and seed germination decreased with the progress of storage period. The seed moisture content and black point incidence were found highest in dole resulting in the lowest percentage of seed germination. The highest percentage of germination was observed in seeds stored in refrigerator, which was followed by polyethylene bag, tin container and earthen pitcher. Kietreiber (1971) reported 26\% increase in black point infection in durum wheat stored in dessicator for 4-6 months with $10 \%$ moisture content under $12-21 \% \mathrm{RH}$ at $18-25^{\circ} \mathrm{C}$. However, Fakir (1988) observed no variation in the prevalence of black point in wheat during $0-4$ months of storage with $10.6-11.3 \%$ moisture content under $70-85 \% \mathrm{RH}$ at 28 $31^{\circ} \mathrm{C}$. The decrease in seed germination with increasing moisture content and length of storage period has been reported by many other workers (Christensen and Kaufmann, 1965; Gupta et al., 1973; Rahman et al., 1985; Cook and Veseth, 1991). Clements (1988) reported that moisture content of seed was higher and seed germination was lower in earthen container than in polyethylene bag and tin container, irrespective of length of storage period and storage conditions.

It has also been evident from the results of the present investigation that the prevalence of field fungi decreased and that of storage fungi increased with the increase in length of storage period. Similar findings in relation to prevalence of these two groups of fungi during storage of wheat seeds have also been reported by other workers (Christensen and Kaufmann, 1965; Ampratwum and McQuitty, 1970; Vechiato et al., 1987; Golzar, 1989; Gooding and Davies, 1997).

Reduction in germination and increase in moisture content and black point incidence of wheat seeds during storage might be due to activity of the storage fungi. The assumption is supported by the fact that during later part of storage period, the prevalence of storage fungi, especially species of Aspergillus and Penicillium increased and germination decreased rapidly. Bipolaris sorokiniana and $A$. alternata, the two important fungal pathogens are primarily responsible for black point disease of wheat seeds in Bangladesh. Their populations decreased gradually with the progress of storage period, but the incidence of black point increased with the increase of storage period. It indicates that the storage fungi are also responsible for deterioration and discolouration of wheat seeds in storage. Such discolouration might have caused or aggravated black point symptoms during storage. Christensen and Kaufmann (1965) clearly demonstrated the increase in moisture content and storage fungi and decrease in germination and field fungi of stored grains during storage. Similar results were also observed by Mian and Fakir (1998) in case of rice seed. 
Among the five types of storage container used, refrigerator appeared to be the best container to store wheat seeds, which was followed by polyethylene bag and tin contamer. In refrigerator, the temperature was $10^{\circ} \mathrm{C}$. Therefore, the activity of storage fungi was the lowest and moisture was not absorbed by the seeds from outside. Polyethylene bag and tin are two airtight storage containers. So, moisture was not absorbed by seeds during high humid months of Bangladesh and activity of the storage fungi was not high. As a result, seed germination was higher and black point incidence was lower in these three types of container as compared to dole and earthen pitcher.

In the present study, it was observed that the population of B. sorokiniana associated with wheat seeds was highest in refrigerator followed by polyethylene bag, tin container and earthen pitcher and lowest in dole. It indicates that when temperature is low and under airtight conditions the pathogen can survive for longer period. In Bangladesh, farmers store their seeds mostly in metallic containers and polyethylene bags or polyethylene-lined gunny bags. So, the pathogen can survive in seeds during storage and is transmitted to the fields when black point affected seeds are used. In dole, the pathogen cannot survive longer time with the seeds. But the germination reduces appreciably due to predominance of Aspergillus spp. when the seeds are stored in dole. Therefore, dole is not advisable for storage of wheat seeds.

\section{References}

Ampratwum, D.B. and J.B. McQuitty. 1970. Some physical factors affecting fungal population in stored wheat. Canad. J. Plant Sci. 50: 47-51.

Anonymous. 1996. International Rules for Seed Testing. International Seed Testing Association (ISTA). Seed Sci. \& Tech. 24 (Supplement): 29-72.

Bilgrami, K.S. and K.K. Sinha. 1983. Aflatoxin contamination in agricultural commodities with special reference to maize and groundnut. In: Recent Advances in Plant Pathology, A. Husain, K. Singh, B.P. Singh and V.P. Agnihotri (eds.), Lucknow Print House (India). pp. 253-263.

Christensen, J.J. 1963. Longevity of fungi in barley kernels. Plant Dis. Reptr. 47: 639-642.

Christensen, C.M. and H.H. Kaufmann. 1964. Spoilage of stored grains. Univ. Minn. Agric. Extension Serv. Folder 226: 4 pp.

Christensen, C.M. and H.H. Kaufmann. 1965. Deterioration of stored grains by fungi. Ann. Rev. Phytopath. 3: 69-84.

Christensen, C.M. and H.H. Kaufmann. 1979. Grain storage: The role of fungi in quality loss. Minneapolis: Univ. Minn. Press. 153 pp.

Clements, D.J. 1988. Wheat seed storage under tropical conditions. In: Wheat Production Constraints in Tropical Environments. A.R. Klatt (ed.). Mexico, D.F.: CIMMYT. pp. 360-365. 
Cook, R.J. and R.J. Veseth. 1991. Wheat Health Management. APS Press, St. Paul, Minnesota, USA. $152 \mathrm{pp}$.

Dharam Vir. 1974. Study of some problems associated with postharvest fungal spoilage of seeds and grains. In: Current Trends in Plant Pathology, S.P. Raychaudhury and J.P. Verma (eds.), Lucknow: Botany Department, Lucknow University. pp. 221-226.

Dharam Vir. 1986. Storage diseases of wheat. In: Problems and Progress of wheat Pathology in South Asia. L.M. Joshi, D.V. Singhand K.D. Srivastava (eds.). Malhotra Publishing House, New Delhi. pp. 296-304.

Fakir, G.A. 1988. Report on investigation into black point disease of wheat in Bangladesh. Bangladesh-German Seed Development Project. Dhaka. 99 pp.

Gilchrist, L.I. 1985. CIMMYT methods for screening wheat for Helminthosporium sativum resistance. In: Wheat for more tropical environments: A Proceeding of the International Symposium. Mexico, D.F.: GFMMYT. pp 149-15 1.

Golzar, H. 1989. Studies on deteriorative abilities of some common storage fungi on wheat seeds. Iranian I. Plant Pathol. 25: 1-4.

Gooding, M.J. and W.P. Davies. 1997. Wheat Production and Utilization: Systems, quality and the environment. CAB International. Univ. Press, Cambridge, UK. 355 pp.

Gupta, V.K., Basant Ram, L.T. Palmer and L.M. Joshi. 1973. Post-harvest fungal damage to wheat due to rains. Indian Phytopath. 26: 156-157.

Hanson, E.W. and J.J. Christensen. 1953. The black point disease of wheat in the United States. Tech. Bull. Minn. Agric. Exp. Sta. 206:30 pp.

Islam, M.R. and G.A. Fakir. 1988. Behaviour of black point affected wheat seeds and the associated black point fungi during storage. Bangladesh J Plant Pathol. 4 (1\&2): 133.

Kietreiber, von Maria. 1971. Discoloured kernels in Triticum durum and T. aestivum. In: The yearbook of Federal Institute of plant protection and seed testing. Viena, Austria. pp 101-115.

Mehrotra, B.S. 1983. The impact of fungal infestation of cereal grains in field and storage. In: Recent Advances in Plant Pathology, A. Husain, K. Singh, B.P. Singh and V.P. Agnihotri (eds,), Lucknow Print House (India). pp. 185-200.

Mian, I.H. and G.A. Fakir. 1998. Effect of container and length of storage on seedborne infection of fungi in rice seed. In: Progiess and Prospect of Seed Pathological Research in Bangladesh: Proc. First National Workshop on Seed Pathology, June 912, 1998, Bangladesh Agricultural University, Mymensingh. p. 7.

Rahman, M.S., I. Hossain, M.A. Mansur, M.A. Rahman and A.C. Barma. 1985. Effect of storage condition on the quality of wheat seed. Bangladesh J. Agril. Sci. 12 (1): 49-54.

Tuite, J.F. 1961. Low incidence of storage molds in freshly harvested seed of soft red winter wheat. Plant Dis. Reptr. 43: 470.

Vechiato, M.H., C.C. Lasca and P.J. Valiarini. 1987. Survival of Helminthosporium sativum on stored wheat (Triticum aestivum) seeds. Fitopathol. Bras. 12: 226-23 1. 